\title{
Islam Sebagai Agama dan Gerakan Politik
}

\section{NADYA RIZKY KHOIRUN NISA'A}

Universitas Muhammadiyah Yogyakarta

$\begin{array}{ll}\text { Judul } & : \text { Islam dan Islamisme } \\ \text { Penulis } & : \text { Bassam Tibi } \\ \text { Penerbit } & : \text { Mizan Pustaka } \\ \text { Kota } & : \text { Bandung } \\ \text { Tahun } & : 2016 \\ \text { Halaman } & : 374 \\ \text { ISBN } & : 978-979-433-968-8\end{array}$

Banyak yang beranggapan bahwa Islam merupakan agama yang tidak luput dari kekerasan. Terlebih setelah tragedi 11 September di New York City, umat Islam menjadi sorotan dunia dan dipandang dengan sebelah mata. Sebuah karya dari Bassam Tibi, seorang guru besar di Jerman tepatnya dari Universitas $\mathrm{G}$

ttingen yang mengabdi sejak 1973 dan pensiun pada tahun 2009 akan membuka mata kita. Beliau merupakan seorang peneliti yang terkenal dengan analisisnya tentang hubungan antara Islam, politik, dan hubungan internasional. Buku ini menjadi pencerahan bagi dunia umumnya dan bagi umat Islam khususnya, mengenai perbedaan antara agama Islam dan Islamisme dengan konsep tentang negaranya. Belakangan ini Islam dan Islamisme sering diabaikan bahkan dihilangkan, namun buku ini menjelaskan pentingnya pemahaman dari dua kata tersebut bagi umat Muslim karena beragama Islam bukan berarti menjadi penghambat bagi perdamaian dan bukan juga sebuah ancaman bagi non-Muslim. Tibi berusaha menyampaikan bahwa Islamisme bukanlah sesuatu yang dibutuhkan oleh peradaban Islam, karena Islamisme merupakan idiologi totalitarian.

Buku ini dibagi menjadi 9 ulasan pokok di luar prakata. Pada bagian prakata, penulis memaparkan tentang pesan-pesan yang akan disampaikan 
pada bukunya. Pesan pertama adalah penegasan perbedaan agama Islam dengan Islamisme. Pesan kedua bahwa Islamisme merupakan ideologi totalitarian, pandangan ini sangat terkait dengan antisemitismenya. Penulis juga menjelaskan bahwa posisinya sebagai penulis berusaha mengkaji Islam dari kerangka yang biasa disebut dengan Islamologi atau suatu ilmu sosial berbasis penelitian yang mengaitkan realitas kelslaman dengan kajian konflik internasional di dunia politik. Penulis juga menjelaskan tujuan penulisan bukunya tak lain untuk menjelaskan berbagai nilai yang berbenturan dan membuka perdebaatan tentang perbedaan antara Islamisme dan Islam.

Pada pembahasan pertama, penulis dengan tegas menjelaskan perbedaan Islam dengan Islamisme "politik yang diagamaisasikan" untuk mempermudah dalam memahami argumen dasar dari buku ini. Disini juga didefinisikan secara lugas ideologi yang menghubungkan agama dengan negara dalam tatanan politik yang berbasis syariat. Pada bagian ini penulis membahas isu-isu dasar antara lain; Islam sebagai nizan Islami, Yahudi, evolusi dari jihad, rekonstruksi syariat, dan pandangan Islam akan sekularisasi serta desekularisasi. Penulis juga membagi 3 kelompok yang akan membantah perbedaan Islam dan Islamisme.

Pembahasan kedua penulis menyoroti din-wa-daulah dan hal yang menjadikan Islamisme menjadi isu global dengan tujuan memperluas dunia Islam dengan tatanan dunia yang baru. Pada bagian ini penulis memaparkan kelompok Islamis bertujuan menggulingkan Perdamaian Westphalia 1648 dengan dasar kepentingan politik, ekonomi, dan sosial berbagai klaim agama. Penulis menjadikan "fundamentalisme agama" sebagai alat analisis yang mengekspresikan Islamfobia benar-benar menyesatkan. Penulis menitikberatkan pada Ideologi Islamis memiliki visi; secara politik, hukum, budaya dan secara militer. Pada pembahasan ini penulis juga menyoroti tokoh Qutb dan Hasan al-Banna serta Yusuf al-Qardhawi.

Pembahasan ketiga banyak menggunakan istilah-istilah seperti antisemitisme, yudeofobia. Penulis juga menyinggung gerakan antisemitis baru yang populer setelah Paus Benediktus XVI mengemukakan pidatonya. Penulis lebih dalam mengkaji pertarungan Sayyid Qutb dengan Yahudi sebagai zionis hingga disepakati piagam Hamas. Isu utama dalam bab ini adalah anti-Zionisme dan anti-Amerikanisme berkamuflase agar mendapatkan dukungan.

Pembahasan keempat berkaitan dengan hubungan antara Islamisme 
dengan demokrasi sudah memicu perdebatan sengit. Pada bab ini Sayyid Qutb menyatakan bahwa demokrasi barat tidak sempurna sehingga memicu dua kasus Islamisme Institusional; AKP dan Ikhwanul Muslimin. Awalnya demokrasi menawarkan masa depan yang lebih baik bagi Islam namun terjadi krisis demokrasi di dunia Arab. Menghadirkan syariah sebagai hukum konstitusional merupakan masalah terbesar pada bab ini.

Pada bagian kelima penulis memberikan pemahaman tentang jihad dan jihadisme serta peranan para ulama di dalamnya. Bab ini juga memaparkan arti Islam dimata Barat dan mengatakankan bahwa Nabi Muhammad hanya memberi perintah menyebarkan iman dengan peperangan. Sedangkan umat Muslim mengartikan Jihad sebagai perintah Al-Qur'an dan akan menggunakan kekerasan hanya kepada mereka yang menolak dakwah Islam. Berbeda dengan Ikhwanul Muslimin yang lebih memilih untuk berperang dalam ide-ide yang lebih menguntungkan. Penulis memaparkan bahwa agama, etnisitas, dan budaya adalah sumber konflik antara Islam dan Barat.

Bab selanjutnya penulis mencoba mempelajari syariah dari berbagai tinjauan seperti; politik syariat, desekularisasi, syariah sebagai hukum kunstitusi, syariat secara universal dalam hukum, syariat dan fikih, serta syariah dan kebebasan. Yang belum pernah terjadi adalah negara Islam didasari dengan hukum syariah.

Pada bab ketujuh penulis membahas perpaduan sekularisasi dan desekularisasi. Agenda pemurnian politik sebenarnya autentisitas. Keautentikan rasional falsafah Islam juga menjadi sorotan pada bab ini, wacana peradaban Islam di masa kejayaannya ditentukan oleh keterbukaan untuk belajar dari liyan. Konflik lama dalam Islam abad pertengahan antara ortodoksi fikih dan rasionalisme filsafat kembali meradang dengan nama dan keadaan yang berbeda.

Mengingat bahwa Islamisme adalah agama politik. Pada bab ini penulis banyak membahas negara-negara Islam yang menjadikan Islamis sebagai solusi dalam pemecahan masalah apapun, seperti di negara Arab Saudi dan Mesir. Penulis juga menyoroti agenda Islamis yang disebut sebagai nizam Islami.

Bagian terakhir Hasan al-Banna, Sayyid Qutb, Abu al-A'ala al-Maududi dan Yusuf al-Qaradhawi merupakan tokoh-tokoh dalam Islamisme dengan tujuan anti demokrasi dan totaliter untuk membentuk tatanan negara dan seluruh politik dunia. Terdapat tiga perbedaan mendasar dalam bab 
ini yaitu; agama politik dan problematika tatanan politik, praktik kekerasan sebagai teror suci dan perang iregular dari para aktor non-negara, terakhir adalah Islamisme dan kerangka konseptual fundamentalisme agama. Bab ini juga membahas kalangan Islam moderat.

Kelebihan buku ini adalah ada banyak informasi menarik khususnya terhadap pandangan Islam sebagai agama dan Islam sebagai gerakan politik. Buku ini sangat penting bagi akademisi khususnya dalam Studi Islam dalam mengkaji dunia Islam yang lebih luas lagi, termasuk untuk mencoba mengkontekstualisasikannya dalam dinamika politik Islam di Indonesia. 